\title{
David Oliver: NHS doctors' licence to challenge
}

\author{
David Oliver consultant in geriatrics and acute general medicine
}

Berkshire

Imagine that you're a head teacher at a state school. You have a professional obligation to give children the best education you can with the resources you have. They have no second chance.

Whatever you may think about workforce gaps, dilapidated buildings, curriculum changes, class sizes, testing, and inspection, you strive to deliver maximum value to the students. You are on the public payroll. If you don't like it you can leave, and plenty do. None of this is incompatible with a simultaneous right and duty to highlight all of the problems you believe compromise teachers' jobs and children's education.

Similar considerations apply in emergency services, social work, the military, local government, and criminal justice. They surely also apply to state employed NHS clinicians. We get on with the job as best we can because patients need us. Why should this preclude simultaneously challenging our political leadership, incompetent or unfair inspection and regulation, underfunding, understaffing, unsafe conditions, unevidenced initiatives, or misleading spin?

George Bernard Shaw was surely right in arguing that "progress depends on the unreasonable man"

Perhaps if we medics had been more belligerent and outspoken when Andrew Lansley's disastrous Health and Social Care Act was being pushed through parliament we could have helped avert the subsequent train wreck. ${ }^{1}$ More recently, during their contract dispute with the government, junior doctors highlighted some very real risks to the service. Many are being increasingly vindicated as these risks become realities. Yet, at the time, they were criticised by politicians and some sections of the media for highlighting these risks.

Doctors have a responsibility to take on leadership roles, minimise variation and waste, and maximise value, safety, and quality. ${ }^{2}$ But our duties shouldn't end there. The General Medical Council's Good Medical Practice guidance is an excellent template for medical professionalism and probity. ${ }^{3}$ It helpfully highlights the responsibilities of doctors in leadership roles. These include a duty to escalate any concerns about risks to patient safety or quality. The GMC highlights doctors' responsibility as clinicians and clinical managers for good stewardship of scarce resources.

For my money, the GMC and some influential medical leadership experts ${ }^{4-6}$ tend to an over-submissive "compliance" model of medical professionalism and leadership. This is centred on being reasonable, within current system constraints, which must themselves be meekly accepted. It's important to be pragmatic and to work collaboratively within the system. But the playwright George Bernard Shaw was surely also right in arguing that "progress depends on the unreasonable man."

State employed doctors need license, encouragement, and protection to raise concerns about health policy, funding, national leadership, and infrastructure. None of us is morally responsible for circumstances we can't control. But we can raise awareness and can influence the people who do have authority and power. And we should certainly be encouraged and protected in doing so.

Competing interests: See www.bmj.com/about-bmj/freelancecontributors/david-oliver.

Provenance and peer review: Commissioned; not externally peer reviewed.

Follow David on Twitter: @mancunianmedic

1 Timmins N. Never again? The story of the Health and Social Care Act 2012. King's Fund 12 July 2012. https://www.kingsfund.org.uk/publications/never-again.

Oliver D. David Oliver: What might the Queen's speech mean for hospital doctors?BMJ 2017;358:j3077

3 General Medical Council. Good medical practice. 2013. www.gmc-uk.org/guidance/good medical_practice.asp

Newbold M. Skirmish over seven day working. BMJ 2015;358:h4082.

5 Lees P. Professionalising medical leadership. Future Hosp J 2015;2:208-10. http:// futurehospital.rcpjournal.org/content/2/3/208.abstract.

6 Lees P. Who are the great medical leaders of our era? Future Hosp J 2015;2:157-8. http: //futurehospital.rcpjournal.org/content/2/3/157.extract.

Shaw GB. Available at https://en.wikiquote.org/wiki/George_Bernard_Shaw (\#124). Published by the BMJ Publishing Group Limited. For permission to use (where not already granted under a licence) please go to http://group.bmj.com/group/rights-licensing/ permissions 